\title{
Chronic But Not Acute Treatment with a Metabotropic Glutamate 5 Receptor Antagonist Reverses the Akinetic Deficits in a Rat Model of Parkinsonism
}

\author{
Nathalie Breysse, ${ }^{1}$ Christelle Baunez, ${ }^{1}$ Will Spooren, ${ }^{2}$ Fabrizio Gasparini, ${ }^{2}$ and Marianne Amalric ${ }^{1}$ \\ ${ }^{1}$ Laboratoire de Neurobiologie Cellulaire et Fonctionnelle, Centre National de la Recherche Scientifique, 13402 Marseille \\ cedex 20, France, and 2Novartis Pharma AG, Basel CH-4002, Switzerland
}

\begin{abstract}
Metabotropic glutamate receptors (mGluRs) have recently been considered as potential pharmacological targets in the treatment of neurodegenerative disorders and particularly in parkinsonism. Within the basal ganglia, receptors of group I (mGluR1 and mGluR5) are widely expressed; the present study was thus aimed at blocking these receptors in a 6-hydroxydopamine (6-OHDA) model of Parkinson's disease in the rat. Considering the prominent expression of mGluR5, we have used the selective mGluR5 antagonist 2-methyl-6-(phenylethynyl)-pyridine (MPEP) to target these receptors. In rats trained to quickly depress a lever after a visual cue, bilateral lesions of the dopaminergic nerve terminals in the striatum produced severe akinetic deficits, which were expressed by increases in delayed responses and reaction times. Acute MPEP injection (1.5, 3, and $6 \mathrm{mg} / \mathrm{kg}$, i.p.) had no effect, whereas chronic administra-
\end{abstract}

Recent findings on the development of motor abnormalities in Parkinson's disease (PD) suggest a crucial involvement of increased glutamatergic activity in basal ganglia circuitry (Wichmann and DeLong, 1997). In experimental models of PD, reduction of excitatory amino acid transmission has thus been suggested to serve as a therapeutic alternative that may improve the motor symptoms in PD (Carlsson and Carlsson, 1989; Bergman et al., 1990; Schmidt et al., 1990; Amalric et al., 1995; Baunez et al., 1995; Rouse et al., 2000; Baron et al., 2002). In parkinsonian patients, surgical therapies have been successfully applied to improve symptomatology (Benabid et al., 1994; Limousin et al., $1995 a, b)$. In addition to this surgical approach, non-invasive pharmacotherapies relying on drug discovery programs are actively pursued.

As a first approach, a number of studies showed that ionotropic glutamate receptor antagonists of the NMDA subtypes could counteract parkinsonian symptoms or act in synergy with L-3,4dihydroxyphenylalanine (L-DOPA) in animal models of PD (Greenamyre and O’Brien, 1991; Schmidt et al., 1992; Ossowska,

\footnotetext{
Received Oct. 5, 2001; revised Feb. 28, 2002; accepted March 28, 2002.

This study was supported by the Centre National de la Recherche Scientifique and by the Fondation France Parkinson (Program Grant to M.A.). N.B. was supported by Direction Générale des Armées. We thank D. Terramorsi for taking care of the animals.

Correspondence should be addressed to M. Amalric, Laboratoire de Neurobiologie de la Cognition, Centre National de la Recherche Scientifique, 31 chemin J. Aiguier, 13402 Marseille cedex 20, France. E-mail: amalric@lncf.cnrs-mrs.fr.

N. Breysse's and C. Baunez's present address: Laboratoire de Neurobiologie de la Cognition, Centre National de la Recherche Scientifique, 13402 Marseille, cedex 20 France.

W. Spooren's present address: Hoffman-La Roche, CH-4070 Basel, Switzerland.
} Copyright (C) 2002 Society for Neuroscience $0270-6474 / 02 / 225669-10 \$ 15.00 / 0$ tion, ineffective in a control group, significantly reversed the akinetic deficits. Alleviation of these deficits was seen after 1 week of treatment, and the preoperative performance was fully recovered after a 3 week treatment of MPEP at all doses. Chronic MPEP also induced ipsilateral rotation in the unilateral 6-OHDA circling model. However, no effect was seen of MPEP $(1.5,3$, or $6 \mathrm{mg} / \mathrm{kg}$, i.p.) on haloperidol-induced catalepsy (1 $\mathrm{mg} / \mathrm{kg}$, i.p.). Altogether, these results suggest a specific role of mGluRs in the regulation of extrapyramidal motor functions and a potential therapeutic value for mGluR5 antagonists in the treatment of Parkinson's disease.

Key words: basal ganglia; metabotropic receptor antagonist; 6-OHDA lesions; Parkinson's disease; reaction time task; glutamate; metabotropic receptors (mGluR5 subtype); MPEP; rat

1994; Danysz et al., 1997; Starr et al., 1997). The alleviation of parkinsonian motor signs was often limited, however, because of the occurrence of uncontrolled side effects at higher dose regimens (hallucinations, cognitive perturbations, postural imbalance) (Amalric et al., 1995; Andine et al., 1999). The narrow window between symptomatic relief and side effects with these NMDA receptor antagonists gave rise to the hypothesis that a modulatory action on glutamate transmission would avoid some of these undesirable side effects.

Recent emphasis has been placed on metabotropic glutamate receptors (mGluRs) in the treatment of neurodegenerative disorders. On the basis of primary sequence, second messenger coupling, and pharmacological profiles, mGluRs can be classified into three subgroups: group I (mGluR1 and mGluR5), group II (mGluR2 and mGluR3), and group III (mGluR4, 6, 7, and 8) (for review, see Conn and Pin, 1997). The expression of mGlu5 receptors in the basal ganglia suggests that this receptor subtype might be an interesting target in the treatment of PD. Indeed, mGlu5 receptors have been implicated as major players in the excitatory drive to the subthalamic nucleus from glutamatergic afferents (Awad et al., 2000). The recent identification of a selective and systemically active ligand for the mGluR5 subtype, i.e., 2-methyl-6-(phenylethynyl)-pyridine (MPEP) (Gasparini et al., 1999), allowed us to evaluate the potential therapeutic benefit in animal models for nervous system disorders (Spooren et al., 2001). The present study therefore tested the effects of MPEP administration in a rat model of PD induced by bilateral 6-OHDA lesions in the striatum. It was shown previously that this model produces profound deficits in a reaction time task (Amalric and Koob, 1987; Amalric et al., 1995; Baunez et al., 1995). The 
effects of acute or chronic application of MPEP were thus tested in this model of akinesia and in additional models of PD: the unilateral 6-OHDA rotation and the haloperidol-induced catalepsy.

\section{MATERIALS AND METHODS \\ Experiment 1: reaction time task}

\section{Animals}

Male Wistar rats ( $n=85$; Iffa Credo, Lyon, France), weighing 110-120 $\mathrm{gm}$ at the beginning of the experiment, were housed in groups of two per cage and maintained in temperature-controlled conditions with a $12 \mathrm{hr}$ light/dark cycle (7 A.M.-7 P.M., lights off). Their food supply was restricted to $15-17 \mathrm{gm} / \mathrm{d}$ per rat to keep them at $80 \%$ of the free-feeding weight of control animals. Water was provided ad libitum.

All procedures were conducted in accordance with the requirements of the French "Ministère de l'agriculture et de la pêche" Décret no. 87-848, October 19, 1987.

\section{Behavioral procedure}

Eight operant boxes (Campden Instruments, Cambridge, UK) were used for the reaction time (RT) task. Each box was equipped with a lever, a food magazine, and a cue light (a $2.8 \mathrm{~W}$ bulb) located above the lever corresponding to the conditioning stimulus (CS). The lever required a force of $0.8 \mathrm{~N}$ for switch closure. A house light located on the ceiling was turned on at the beginning of the testing session. Each box was placed in a wooden sound-attenuating cabinet that was ventilated by a low-level noise fan. Rats were trained to depress the lever and wait for the onset of the visual trigger stimulus presented after four randomly and equiprobably generated intervals $(0.5,0.75,1.00$, or $1.25 \mathrm{sec}$.). To be rewarded by a food pellet ( $45 \mathrm{mg}$; Phymep, Paris, France), the rat was required to release the lever with a RT below $600 \mathrm{msec}$. The RT was measured in milliseconds from the onset of the stimulus to the lever release. Each daily session ended after 100 trials. Performance was evaluated by recording the number of correct and incorrect (nonrewarded) responses as either "premature," corresponding to early withdrawal of the lever (before the onset of the CS), or "delayed," when the lever was released with RT above $600 \mathrm{msec}$. After training, rats were tested for 6 consecutive days in the RT task from preoperative baseline values before surgery. After a $7 \mathrm{~d}$ postoperative recovery period, they were tested again for 24 sessions up to $32 \mathrm{~d}$.

\section{Dopamine lesion}

The animals were anesthetized by an intramuscular injection of xylazine $(15 \mathrm{mg} / \mathrm{kg})$ and ketamine $(100 \mathrm{mg} / \mathrm{kg})$ and placed in a stereotaxic instrument (David Kopf Instruments) with the incisor bar positioned $-3.0 \mathrm{~mm}$ under the interaural line for surgical procedures based on coordinates of Paxinos and Watson (1986). Lesioned animals received a bilateral injection of 6-OHDA hydrochloride (Sigma Aldrich, Lyon, France) $(4 \mu \mathrm{g} / \mu \mathrm{l}, 3 \mu \mathrm{l}$ per side) in the striatum at the following coordinates: anteroposterior (AP) $+0.2 \mathrm{~mm}$, lateral (L) $\pm 3.5 \mathrm{~mm}$, dorsoventral (DV) $-4.8 \mathrm{~mm}$ (from skull) according to bregma. The sham control group received the vehicle alone (ascorbate solution, $0.1 \mathrm{mg} /$ $\mathrm{ml}$ ) in the dorsal striatum. The infusion was made with a micropump over 9 min using a $10 \mu$ l Hamilton microsyringe, connected by a Tygon tubing fitting to the 30 gauge stainless steel injector needles. A 1 week recovery period was allowed before the animals were again tested daily on the behavioral task.

\section{Drugs}

6-OHDA (Sigma Aldrich) was dissolved in ascorbic acid solution (0.1 $\mathrm{mg} / \mathrm{ml}$ in $0.9 \%$ saline) to prevent oxidation. MPEP hydrochloride (Novartis, Basel, Switzerland) was dissolved in distilled water and injected intraperitoneally in a volume of $1 \mathrm{ml} / \mathrm{kg}$.

\section{Experimental procedure}

Acute MPEP treatment. Twenty-four rats were used to test the effects of an acute injection of MPEP. Control rats ("sham"; $n=9$ ) and dopamine (DA)-depleted rats (6-OHDA; $n=15)$ were tested on the RT task. The effects of the lesion were tested between days 9 and 14 after surgery. Each group (sham vs 6-OHDA) was then divided into three different groups receiving three doses of MPEP $(0.3,1$, or $3 \mathrm{mg} / \mathrm{kg})$ in a different order of injection over 3 weeks following a Latin-square design. Injections were performed once a week over 3 weeks.

Chronic MPEP treatment. The effects of 6-OHDA lesion were tested between postoperative days 9 and 14. MPEP was then injected intraperitoneally for 3 weeks (days 15-31 after surgery), and the animals were immediately tested in the RT task. The animals were divided into four subgroups depending on the dose of MPEP (MPEP $0, n=10$; MPEP 1.5 , $n=7$; MPEP $3, n=10$; MPEP $6, n=10$ ). The effects of MPEP chronic treatment were tested further in a control group of animals (sham operated) under the same experimental conditions. MPEP was chronically injected intraperitoneally for 3 weeks at the same doses (i.e., $0,1.5$, 3 , and $6 \mathrm{mg} / \mathrm{kg} ; n=6$ for each group, except $n=8$ for the 0 group) between postoperative days 9 and 31 .

\section{Statistical analysis}

The effects of dopamine depletion and MPEP treatments on RT performance were evaluated on each variable (i.e., number of correct, premature, and delayed responses and RTs) averaged across each session. For each variable, the data were submitted to a mixed design ANOVA with different subgroups ("6-OHDA" vs "MPEP1.5" vs "MPEP3" vs "MPEP6") and different orders (for the acute experiment) as the between-subject factor, the sessions ( 6 before surgery, 6 after surgery, and 18 with chronic treatment or the acute treatment sessions) as the within-subject factors, as appropriate. Post hoc multiple comparisons between groups were made using simple main effects analysis and Fisher test, as appropriate.

To detect whether rats had a preparatory motor strategy to perform the conditioned reaction time task (using the visual stimulus occurrence, i.e., the shorter RTs are associated with the longer delay), RTs were plotted as a function of the intervals preceding the CS at preoperative day 2 and postoperative days 12 and 31 . The ANOVA involved two within-subjects factor: the four various intervals and the preoperative and postoperative sessions (Statview 5.0 program, Abacus concept).

\section{Histology}

At the end of the experiment, animals were killed by decapitation. The brains were then removed and frozen to $-80^{\circ} \mathrm{C}$. Coronal $10 \mu \mathrm{m}$ tissue sections were cut at $-20^{\circ} \mathrm{C}$ using a microtome cryostat (Leica CM3050) at the level of the striatum.

The binding of $\left[{ }^{3} \mathrm{H}\right]$-mazindol to dopamine uptake sites in the striatum was measured according to the procedure described by Javitch et al. (1985). Briefly, sections were air dried and rinsed for $5 \mathrm{~min}$ at $4^{\circ} \mathrm{C}$ in 50 $\mathrm{mm}$ Tris buffer with $120 \mathrm{~mm} \mathrm{NaCl}$ and $5 \mathrm{~mm} \mathrm{KCl}$. They were then incubated for 40 min with $\left.15 \mathrm{~nm} \mathrm{[}{ }^{3} \mathrm{H}\right]$-mazindol (NEN DuPont; specific activity $17 \mathrm{Ci} / \mathrm{mm}$ ) in $50 \mathrm{~mm}$ Tris buffer containing $300 \mathrm{~mm} \mathrm{NaCl}$ and 5 $\mathrm{mm} \mathrm{KCl}$ added with $0.3 \mathrm{~mm}$ desipramine to block the noradrenalin transporter. Nonspecific binding was determined by incubating some sections in the same solution plus $30 \mathrm{~mm}$ benztropine. Sections were rinsed twice for $3 \mathrm{~min}$ in the incubation medium without mazindol and for $10 \mathrm{sec}$ in distilled water and were air dried. Autoradiographs were generated by apposing the sections to ${ }^{3} \mathrm{H}$-sensitive screen (Raytest) for $7 \mathrm{~d}$ and were further quantified with a $\beta$ imager (Fuji-Bas 5000).

\section{Experiment 2: turning behavior}

\section{Animals}

Male Sprague Dawley rats (Iffa Credo, Les Oncins, France; $n=120$ ) weighing $250-280 \mathrm{gm}$ at the time of surgery (see below) were used. The animals were housed four per cage in a temperature-controlled room $\left(22 \pm 1^{\circ} \mathrm{C}\right)$ under artificial illumination (6 A.M.-6 P.M., lights on) with ad libitum access to water and food (Ecosan, Eberle Nafag AG, Gossau, Switzerland).

\section{Surgery}

Before surgery, all animals received an injection of desipramine hydrochloride $(30 \mathrm{mg} / \mathrm{kg}$, i.p.; USPC Inc., Rockville, MD) to protect noradrenergic cells. One hour later the animals received an injection of pentobarbital (55 mg/kg, i.p.; Vetanarcol, Veterinaria AG, Zurich, Switzerland) and were subsequently placed (under deep anesthesia) in a stereotaxic apparatus. A unilateral lesion was made by injecting $9 \mu \mathrm{g}$ 6-OHDA (hydrobromide; Fluka Chemie AG, Buchs, Switzerland) in 0.7 $\mu \mathrm{l}$ ascorbic acid solution (dilution $1 \mathrm{mg} / \mathrm{ml}$ ) over $10 \mathrm{~min}$ into the left medial forebrain bundle [coordinates: AP $3.6 \mathrm{~mm}$ (from bregma), L 1.1 $\mathrm{mm}$ (from midline), and DV $-7.9 \mathrm{~mm}$ (from dura); Pellegrino et al. (1997)]. The control group received the ascorbic solution at the same 
coordinates. The injection was aimed at the rostral pole of the substantia nigra where the ascending nigrostriatal bundle converges to produce a so-called near-maximal lesion (Spooren et al., 1999). After the injection, the needle was kept in place for another $10 \mathrm{~min}$ to allow diffusion of the toxin away from the injection site and to prevent backflow.

After surgery, the animals were allowed to recover for at least $21 \mathrm{~d}$ before they were tested in the rotameter. Selection of animals to be included in the studies was performed using the rotational response to apomorphine $(0.25 \mathrm{mg} / \mathrm{kg}$, s.c. $)$, and only responders $(>100$ net rotations) to this treatment were used.

\section{Procedures for rotameter testing}

All animals were tested in automated rotameter cylinders (TSE, Bad Homburg, Germany), and the number of rotations (ipsilateral and contralateral) was recorded automatically.

The animals ( $n=16$ for each treatment group) received one injection with MPEP (doses: 7.5 or $30 \mathrm{mg} / \mathrm{kg}$, p.o.) or vehicle (methylcellulose, $0.5 \%$ ) per day for $7 \mathrm{~d}$. Considering the bioavailability of MPEP by oral administration, the doses of MPEP injected by mouth were comparable to those administered intraperitoneally in the RT task. They were chosen according to earlier studies examining the effects of acute MPEP on rotation (Spooren et al., 1999). The turning behavior after the first and seventh injection were recorded automatically (see above) in the rotameter. The effects of injections two to six were not recorded, and after the injection the animals immediately returned to their home cages.

\section{Statistical analysis}

The number of net rotations (i.e., the number of contralateral rotations minus the number of ipsilateral rotations) per treatment was statistically evaluated by means of a repeated measures ANOVA with one factor between groups (dose: $0,7.5$, or $30 \mathrm{mg} / \mathrm{kg}$, p.o.) and two factors within groups (repeated), i.e., tests days (day 1 or 7 ) and time points $(10,20,30$, $40,50,60,70,80$, and $90 \mathrm{~min}$ after injection). The number of net rotations at distinct time points between treatment groups [vehicle vs MPEP ( 7.5 or $30 \mathrm{mg} / \mathrm{kg}$, p.o.) or within treatment groups (one injection vs seven injections)] were compared using an unpaired and paired $t$ test, respectively; $p<0.05$ was considered as statistically significant (Software: Systat 10.0).

\section{Experiment 3: catalepsy}

To compare the effects of acute and chronic administration of MPEP on haloperidol-induced catalepsy, the animals were tested in the horizontal bar test as follows. Each animal was gently placed with its forepaws on a metal rod suspended $9 \mathrm{~cm}$ above the floor, and the time elapsing before it climbed down from the bar was recorded in seconds. The mixed D1/D2 dopaminergic receptor antagonist haloperidol (Haldol injectable solution; Janssen, Boulogne, France) was dissolved in physiological $0.9 \%$ saline solution and injected systemically at a dose of $1 \mathrm{mg} / \mathrm{kg}$. In the two experimental procedures (acute vs chronic) haloperidol (or its solvent) was injected $20 \mathrm{~min}$ before MPEP injection, and catalepsy was measured every $20 \mathrm{~min}$ during the $3 \mathrm{hr}$ testing.

Acute MPEP treatment on haloperidol-induced catalepsy. Twenty-one rats were used to test the effects of an acute injection of MPEP on the cataleptogenic effects of haloperidol. The animals were divided into three groups depending on the dose of MPEP (MPEP $0, n=7$; MPEP $3, n=7$; MPEP $6, n=7$ ). A group of eight control rats received haloperidol vehicle $20 \mathrm{~min}$ before MPEP solvent injection.

Chronic MPEP treatment on haloperidol-induced catalepsy. Thirty-two rats were used to test the effects of chronic injection of MPEP on the cataleptogenic effects of haloperidol. The rats were divided into four groups depending on the dose of MPEP (MPEP $0, n=8$; MPEP 1.5, $n=$ 8; MPEP $3, n=8$; MPEP $6, n=8$ ). Each animal received a 3 week treatment with MPEP before receiving the haloperidol injection.

\section{Statistical analysis}

Catalepsy data were analyzed nonparametrically by performing a multiple Kruskal-Wallis "H" test, and the median latency was calculated for each dose and for each 20 min period. Individual comparisons were performed using the nonparametric Mann-Whitney $U$ test.
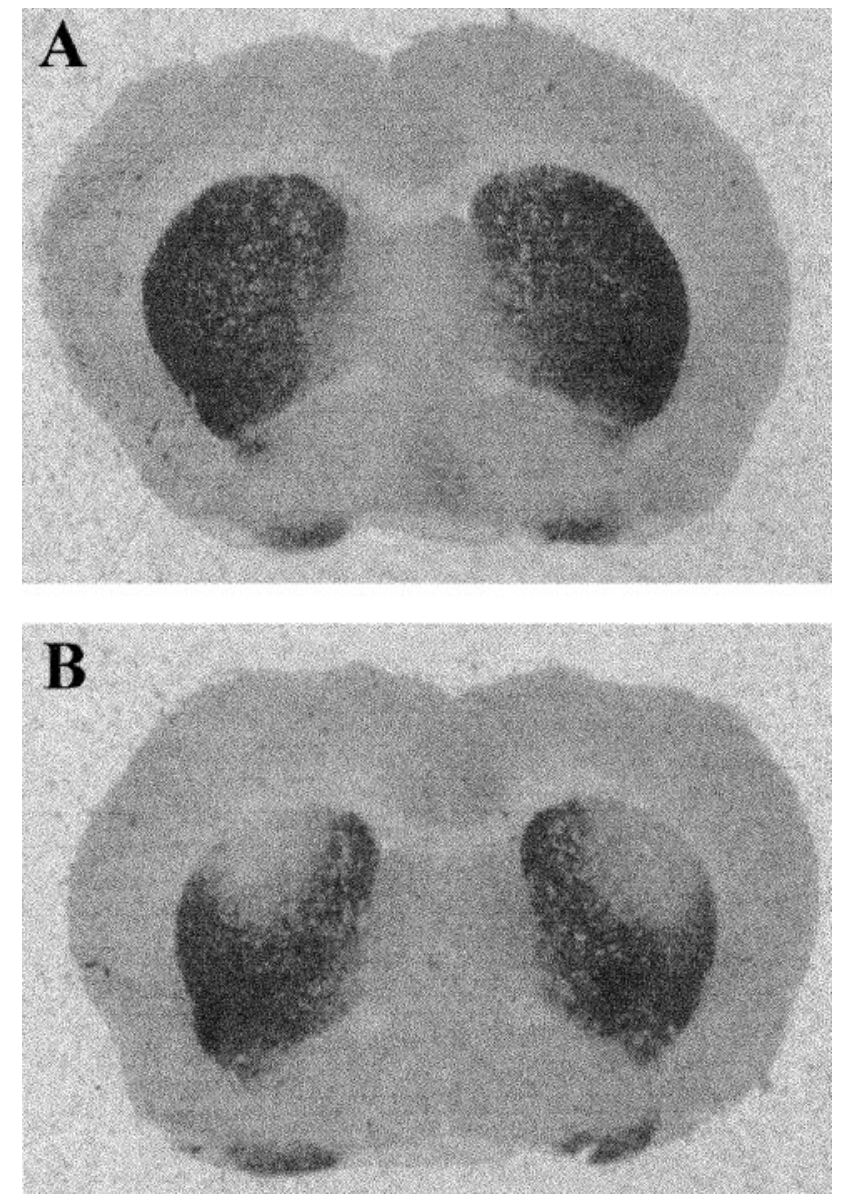

Figure 1. Binding of $\left[{ }^{3} \mathrm{H}\right]$-mazindol to dopamine uptake sites at the striatum level. Photomicrographs comparing the level of $\left[{ }^{3} \mathrm{H}\right]$-mazindol labeling in striatal sections from a control animal $(A)$ and a bilaterally lesioned animal $(B)$. The lack of mazindol binding in $B$ shows the restricted size of the 6-OHDA lesion in the dorsal striatum as compared with sham animals.

\section{RESULTS}

\section{Experiment 1: reaction time task Histology}

The binding of $\left[{ }^{3} \mathrm{H}\right]$-mazindol to dopamine uptake sites in the striatum as determined on coronal sections was used to delineate the extent of dopamine depletion induced by the bilateral striatal 6-OHDA injections (Fig. 1). It was found that the dopamine lesions were consistently restricted to the dorsolateral part of the striatum at the rostral level and extended more ventrally at the more caudal levels (end of the anterior commissure).

\section{6-OHDA lesion effect on correct and incorrect responses}

The effects induced by 6-OHDA infusion into the dorsal part of the striatum were analyzed on postoperative days 9-14. As illustrated in Table 1 and Figure 2, the number of correct responses was markedly reduced as compared with the preoperative levels within each of the five lesioned groups (i.e., acute, 6-OHDA, MPEP1.5, MPEP3, and MPEP6 groups). 6-OHDA lesions resulted in a significant decrease in the correct responses whatever the group tested $(p<0.05$; paired $t$ test after significant ANOVA, $\left.F_{(4,56)}=21.60, F_{(4,36)}=3.30, F_{(4,24)}=4.82, F_{(4,36}\right)=$ 12.19 and 8.25$)$. This effect was also found to be significantly different from correct responses of the sham-operated group 
Table 1. Effects of acute MPEP treatment on RT task performance

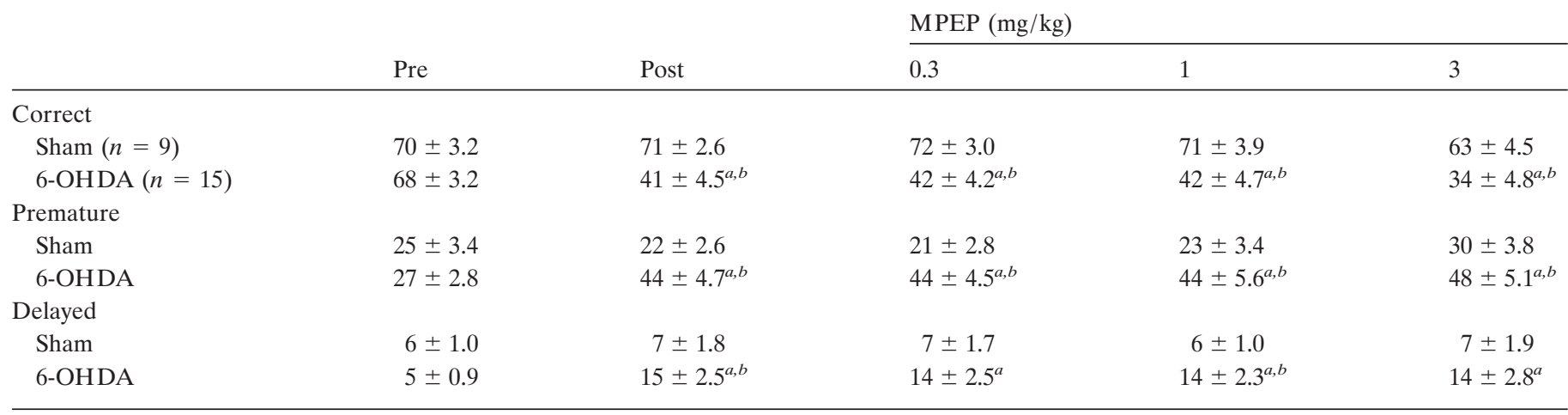

The values correspond to the mean number of correct, premature, and delayed responses during different sessions: one preoperative (pre); one postoperative (post) at day 12 after the lesion; and on the session recorded immediately after MPEP injections at various doses $(0.3,1$, and $3 \mathrm{mg} / \mathrm{kg})$, in sham animals and 6-OHDA-lesioned rats. ${ }^{a} p<0.05$, paired $t$ test, as compared with sham group after significant ANOVA.

${ }^{b} p<0.05$, paired $t$ test, as compared with preoperative performance after significant ANOVA.
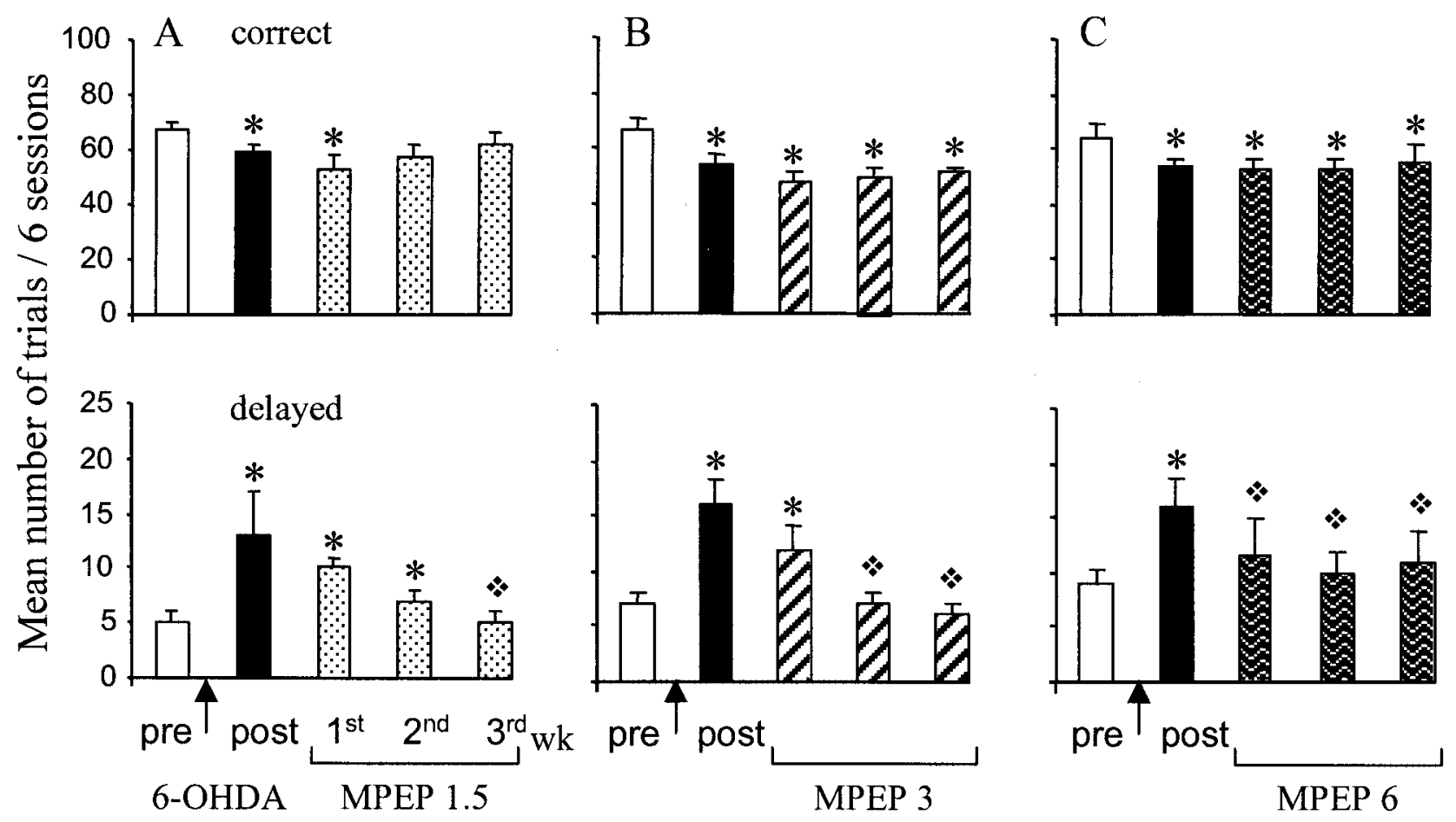

Figure 2. Effects of chronic MPEP treatment on correct and delayed performance after 6-OHDA lesion. The vertical axes give the mean number of trials \pm SEM per block of six sessions for the two variables measured (correct and delayed responses). The effects are measured during various blocks of six sessions corresponding to the following: one block before the surgery ( pre), one from day 9-14 after lesion (post), and three blocks during MPEP chronic treatment from days 15-20, 21-26, and 27-32 after lesion, respectively, of the first, second, and third week. The effects induced by the different doses of MPEP $[1.5 \mathrm{mg} / \mathrm{kg}(A), 3 \mathrm{mg} / \mathrm{kg}(B)$, and $6 \mathrm{mg} / \mathrm{kg}(C)]$ are compared with the preoperative and postoperative levels. *, Significant difference from preoperative performance $(p<0.05$; paired $t$ test after significant ANOVA). Significant difference from postoperative performance $(p<0.05$ paired $t$ test after significant ANOVA).

$(p<0.05$; Newman-Keuls test) and greater in magnitude in the "acute" 6-OHDA group than the "chronic" group because of a significant increase in premature responding (Table 1). This was previously found to result from slightly more ventral diffusion of the 6-OHDA neurotoxin in the striatum (Amalric et al., 1995). The effects of 6-OHDA lesions were long lasting, and no recovery of baseline performance was observed $32 \mathrm{~d}$ after surgery in the 6-OHDA group (data not shown).

The decreased number of correct responses was mainly caused by a significant increase of delayed responses in all the lesioned groups $(p<0.05$; paired $t$ test after significant respective ANOVA,
$F_{(4,56)}=5.59, F_{(4,36)}=7.02, F_{(4,24)}=4.78, F_{(4,36)}=10.43$ and $8.03)$. This effect was also significant in comparison with sham control group performance ( $p<0.05$; Newman-Keuls test).

\section{Reaction time and motor readiness}

In addition, the dopamine depletion in the dorsal striatum significantly increased RTs when compared with preoperative values $(p<0.05$; paired $t$ test) (see Fig. $4 A$ ). At day 32 after lesion, RTs averaged a value of $422 \pm 25.25 \mathrm{msec}$ in comparison with $330 \pm$ $18 \mathrm{msec}$ on day 3 preceding the lesion ( $p<0.05$; paired $t$ test). We also investigated whether 6-OHDA lesion disrupted the re- 


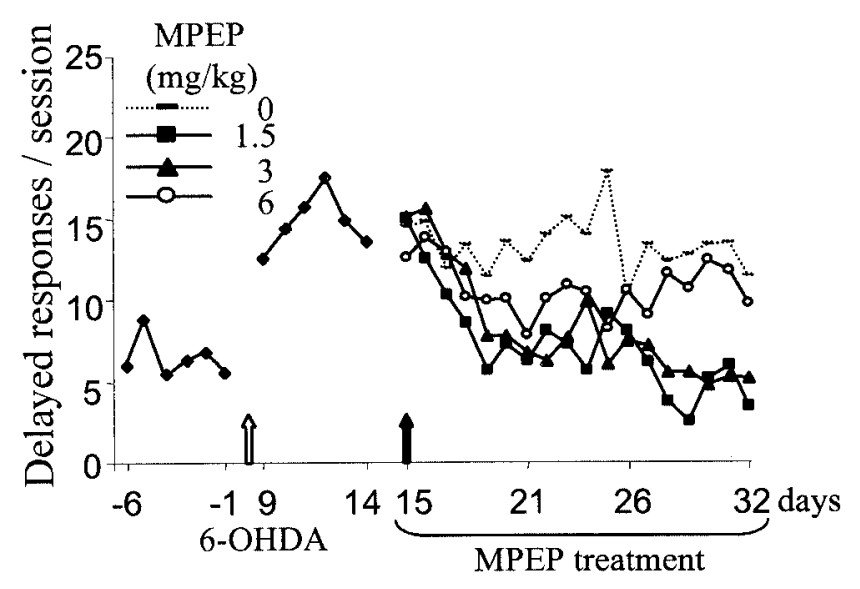

Figure 3. Chronic MPEP treatment on delayed responses over time in the RT task. The mean number of delayed responses per session is illustrated for the 6 preoperative sessions (days -6 to -1 ), the 6 postoperative sessions (days 9-14), and the 18 sessions (days 15-32) of chronic treatment with distilled water, MPEP $1.5(n=7)$, MPEP $3(n=10)$, or MPEP $6(n=10)$. Animals were tested every day in a 100 -trial session.

sponse preparatory processes, also termed "motor readiness." It was found that RTs significantly decreased as a function of the variable intervals (significant "interval" effect ANOVA, $F_{(3,24)}=$ 7.80 for preoperative performance), suggesting optimal motor preparatory processes. This effect on motor readiness remained significant whatever the postoperative day (ANOVA, $F_{(3,24)}=$ 7.61 and 3.03 at 12 and 32 performance days after lesion, respectively).

\section{Acute MPEP treatment on correct and incorrect responses}

No significant effect of the order of injection of the various doses tested according to the Latin-square design was found for any variable ("order" effect, all $F_{(2,18)}<0.77$; interaction order $\times$ "dose," all $F_{(6,54)}<1.18$ for all measures). As shown in Table 1 , the acute treatment with various doses of $\operatorname{MPEP}(0.3,1$, and 3 $\mathrm{mg} / \mathrm{kg}$ ) had no effect on the behavioral performance after the 6-OHDA lesion; the number of correct responses remained significantly lower than the preoperative level ( $p<0.05$; paired $t$ test after significant ANOVA, $\left.F_{(4,56)}=21.61\right)$, whereas the number of delayed and premature responses remained significantly higher $\left(p<0.05\right.$; paired $t$ test after significant ANOVA, $F_{(4,56)}=$ 5.59; and ANOVA, $F_{(4,56)}=6.29$, respectively).

\section{Chronic MPEP treatment on correct and incorrect responses}

6-OHDA. Chronic treatment with MPEP normalized the number of delayed responses of 6-OHDA-lesioned rats at all doses tested, as shown in Figure 2. One week of treatment with $6 \mathrm{mg} / \mathrm{kg}$ MPEP was sufficient to produce this beneficial effect $(p<0.05$; paired $t$ test comparing the 3 weeks of treatment with post-lesion level), whereas 2-3 weeks of treatment at a lower dose were required to produce the same effect ( 3 and $1.5 \mathrm{mg} / \mathrm{kg}$ ). At the end of the chronic treatment with MPEP, all selected doses had induced a full recovery of these responses in comparison with postoperative level of performance $(p<0.05$; paired $t$ test; after significant treatment effect ANOVA, $F_{(4,36)}=8.03, F_{(4,36)}=10.43, F_{(4,24)}=$ 4.78 for 6,3 , and $1.5 \mathrm{mg} / \mathrm{kg}$, respectively). The time effect of this recovery is illustrated as day-by-day performance in Figure 3.

MPEP at a dose of $1.5 \mathrm{mg} / \mathrm{kg}$ normalized the number of correct responses at the second week of treatment and this effect remained stable until the end of the experiment (no significant difference between pretreatment and second and third week of treatment). This effect was not observed after MPEP treatment at the doses of 3 and $6 \mathrm{mg} / \mathrm{kg}$. MPEP was found to induce an increase in premature responding that prevented the normalization of correct responses (Table 2) ( $p<0.05$; paired $t$ test; after significant "treatment" effect on premature responses ANOVA, $F_{(4,36)}=12.65$ and 4.23 , respectively).

Control group. Chronic treatment with MPEP at the same doses in a control group of animals (i.e., no lesion), trained previously in the RT task, did not significantly modify the number of correct, premature, or delayed responses, except in the group treated with $3 \mathrm{mg} / \mathrm{kg}$ MPEP. Chronic treatment with $3 \mathrm{mg} / \mathrm{kg}$ MPEP was found to transiently decrease the number of correct responses (ANOVA, $F_{(4,20)}=3.21 ; p<0.05$ ) associated with a nonsignificant increase in premature responding (Table 3 ). However, no reduction of delayed responses was observed at any dose tested in the control animals, suggesting a selective effect of the compound in 6-OHDA-lesioned animals in this parameter. No ataxia or any debilitating effects were observed on behavior whatever the dose of MPEP used.

Reaction time and motor readiness. The increase in RTs induced by a DA depletion in the dorsal striatum was totally reversed at day 32 after lesion in animals treated with either 1.5 or $3 \mathrm{mg} / \mathrm{kg}$ (no significant difference when compared with preoperative performance; $p>0.05$; paired $t$ test) (Fig. $4 B, C$ ). The motor readiness effect was not affected by chronic treatment with either 1.5 or $3 \mathrm{mg} / \mathrm{kg}$ MPEP [significant interval effect ANOVA, $F_{(3,18)}=5.69$ and $F_{(3,24)}=7.14$ for day 32 after lesion performance in the two MPEP groups (1.5 and $3 \mathrm{mg} / \mathrm{kg}$, respectively)].

\section{Experiment 2: turning behavior}

The ANOVA indicated statistical significance for factors dose $\left(F_{(2,48)}=8.81\right)$, test day $\left(F_{(1,48)}=7.19\right)$, time $\left(F_{(3,384)}=16.22\right)$, and the interaction test $\times$ time point $\left(F_{(8,384)}=8.48\right)$ using the number of net rotations (contralateral - ipsilateral rotations) as dependent variable.

\section{Vehicle treatment}

At no time point were statistically significant differences found in the number of net rotations within vehicle-treated animals after the chronic (seven times) treatment in comparison with the first (acute) vehicle injection (Fig. 5).

\section{Vehicle versus MPEP}

After the acute and chronic vehicle treatment, the animals exhibited a preference for spontaneous contralateral rotations during the registration period of $90 \mathrm{~min}$. In contrast, after the acute and chronic treatment with MPEP (one time and seven times 7.5 or 30 $\mathrm{mg} / \mathrm{kg}$, p.o.), an ipsilateral rotation preference was found that resulted in statistically significant increases in the number of ipsilateral net rotations at distinct time points as compared with acute and chronic vehicle controls (Fig. 5).

\section{MPEP treatment (acute versus chronic)}

Chronic (seven times) application of MPEP (7.5 and $30 \mathrm{mg} / \mathrm{kg}$, p.o.) induced a significant increase in the number of (ipsilateral preference) net rotations 30 and $40 \mathrm{~min}$ after the injection as compared with the acute treatment with these doses of MPEP.

\section{Experiment 3: catalepsy}

Haloperidol $(1 \mathrm{mg} / \mathrm{kg}$ ) produced a profound increase in catalepsy as shown by a progressive increase in the median latency to step down the rod over time as compared with controls $(p<0.05$; 


\begin{tabular}{|c|c|c|c|c|c|}
\hline MPEP $(\mathrm{mg} / \mathrm{kg})$ & Pre & Post & First week & Second week & Third week \\
\hline 0 & $28 \pm 3.2$ & $28 \pm 3.2$ & $28 \pm 3.1$ & $27 \pm 2.5$ & $29 \pm 2.4$ \\
\hline 1.5 & $28 \pm 4.0$ & $30 \pm 5.0$ & $37 \pm 4.0$ & $35 \pm 6.0$ & $34 \pm 5.0$ \\
\hline 3 & $27 \pm 2.5$ & $29 \pm 3.6$ & $41 \pm 3.5^{a, b}$ & $41 \pm 2.6^{a, b}$ & $44 \pm 1.6^{a, b}$ \\
\hline 6 & $26 \pm 3.0$ & $29 \pm 3.0$ & $39 \pm 4.0^{a, b}$ & $38 \pm 4.0^{a, b}$ & $33 \pm 3.0$ \\
\hline
\end{tabular}

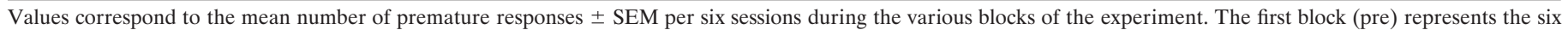

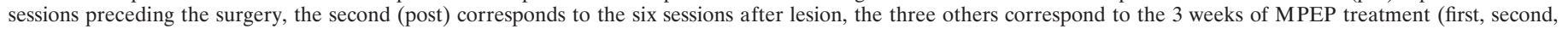
and third weeks).

${ }^{a}$ Significant difference from preoperative performance ( $p<0.05$ paired $t$ test after significant ANOVA).

${ }^{b}$ Significant difference from postoperative performance ( $p<0.05$ paired $t$ test after significant ANOVA).

\begin{tabular}{|c|c|c|c|c|c|}
\hline MPEP (mg/kg) & Pre & Post & First week & Second week & Third week \\
\hline \multicolumn{6}{|l|}{ Correct } \\
\hline 0 & $67 \pm 4.3$ & $68 \pm 2.0$ & $70 \pm 2.6$ & $68 \pm 4.7$ & $69 \pm 4.2$ \\
\hline 1.5 & $69 \pm 4.3$ & $64 \pm 5.6$ & $62 \pm 5.7$ & $64 \pm 6.0$ & $62 \pm 3.0$ \\
\hline 3 & $67 \pm 4.8$ & $65 \pm 2.7$ & $58 \pm 4.0^{a}$ & $59 \pm 5.0^{a}$ & $58 \pm 6.0$ \\
\hline 6 & $68 \pm 3.9$ & $63 \pm 2.0$ & $61 \pm 3.9$ & $59 \pm 6.1$ & $56 \pm 3.0$ \\
\hline \multicolumn{6}{|l|}{ Premature } \\
\hline 0 & $28 \pm 4.7$ & $27 \pm 1.7$ & $24 \pm 1.7$ & $26 \pm 4.8$ & $25 \pm 3.9$ \\
\hline 1.5 & $25 \pm 4.3$ & $30 \pm 5.8$ & $30 \pm 5.6$ & $28 \pm 6.0$ & $31 \pm 4.0$ \\
\hline 3 & $27 \pm 5.2$ & $28 \pm 2.1$ & $36 \pm 4.7$ & $36 \pm 5.0$ & $37 \pm 6.0$ \\
\hline 6 & $26 \pm 3.7$ & $31 \pm 1.9$ & $30 \pm 3.7$ & $35 \pm 6.1$ & $35 \pm 5.0$ \\
\hline \multicolumn{6}{|l|}{ Delayed } \\
\hline 0 & $5 \pm 1.4$ & $5 \pm 1.1$ & $6 \pm 1.2$ & $6 \pm 1.2$ & $6 \pm 1.6$ \\
\hline 1.5 & $6 \pm 1.2$ & $7 \pm 1.7$ & $9 \pm 1.5$ & $8 \pm 2.0$ & $7 \pm 1.0$ \\
\hline 3 & $6 \pm 1.2$ & $7 \pm 2.7$ & $6 \pm 1.7$ & $5 \pm 1.0$ & $5 \pm 2.0$ \\
\hline 6 & $7 \pm 1.0$ & $6 \pm 2.0$ & $9 \pm 2.4$ & $6 \pm 2.5$ & $5 \pm 2.0$ \\
\hline
\end{tabular}

Values correspond to the mean number of correct, premature, and delayed responses during the different sessions: preoperative (pre), postoperative (post), and the 3 weeks of treatment at the various doses of $\operatorname{MPEP}(0,1.5,3$, and $6 \mathrm{mg} / \mathrm{kg})$.

${ }^{a}$ Significant difference from postoperative performance ( $p<0.05$ paired $t$ test after significant ANOVA).

Mann-Whitney $U$ test after Kruskal-Wallis test; $H=80.65$ and 103.68 for the first and second experiment, respectively) (Fig. $6 A, B)$. Catalepsy induced by haloperidol was not significantly antagonized by the acute injection of MPEP (3 and $6 \mathrm{mg} / \mathrm{kg}$, i.p.; $p>0.05)$, although $3 \mathrm{mg} / \mathrm{kg}$ MPEP showed a trend toward reversal of catalepsy ( $p=0.07) 150 \mathrm{~min}$ after haloperidol injection (Fig. $6 A$ ). In contrast, $6 \mathrm{mg} / \mathrm{kg}$ MPEP did not modify the cataleptic state of the rats. When injected chronically for 3 weeks at whatever the dose tested $(1.5,3$, and $6 \mathrm{mg} / \mathrm{kg})$, MPEP did not significantly influence haloperidol-induced catalepsy (Fig. 6B).

\section{DISCUSSION}

The present results demonstrate that chronic but not acute treatment with MPEP, i.e., a selective mGluR5 antagonist, has remarkable beneficial effects on the expression of certain deficits in a reaction time task induced by bilateral injections of 6-OHDA into the striatum. In this rodent model of Parkinson's disease, the dopaminergic lesions impaired the performance by increasing the number of delayed responses and lengthening RTs, which suggests a deficit in motor planning. These akinetic deficits were fully reversed by MPEP treatment at all doses tested $(1.5,3$, and 6 $\mathrm{mg} / \mathrm{kg}$ ). Animals treated with the lowest doses of MPEP were able to reach all prelesion levels of performance within 3 weeks. Interestingly, acute injections of MPEP in 6-OHDA animals or chronic treatment at the same doses in nonlesioned animals did not modify the performance. Furthermore, it is shown that chronic treatment with MPEP also significantly increases ipsilateral rotations in the classical unilateral 6-OHDA lesion circling model. In contrast, in the model of PD involving dopamine receptor antagonist administration (i.e., the catalepsy test), chronic treatment with MPEP was ineffective.

Recent evidence suggests that the neurodegeneration of the dopamine neurons of the substantia nigra pars compacta, eliciting the motor symptoms of PD, results in an increase in glutamatergic activity at the striatal and subthalamic nucleus (STN) levels of the basal ganglia. Ultimately, the increase in glutamate activity of the STN is responsible for overactivity in the basal ganglia output structures [i.e., internal segment of the globus pallidus (GPi) and the substantia nigra pars reticulata $(\mathrm{SNr})]$ that are also directly under the control of the striatum (Rouse et al., 2000). In the primate 1-methyl-4-phenyl-1,2,3,6-tetrahydropyridine model of $\mathrm{PD}$, the expression of the mRNA encoding for cytochrome oxidase subunit I, a molecular marker for functional neuronal activity, was found to be enhanced in the STN and in the SNr/GPi (Vila et al., 1997). Therefore, several attempts have been made to reduce STN overactivity by using pharmacological as well as surgical tools. In parkinsonian patients, high-frequency stimulation of the STN, which blocks STN neuronal activity (Benazzouz et al., 2000; Beurrier et al., 2001), alleviates the motor symptoms 


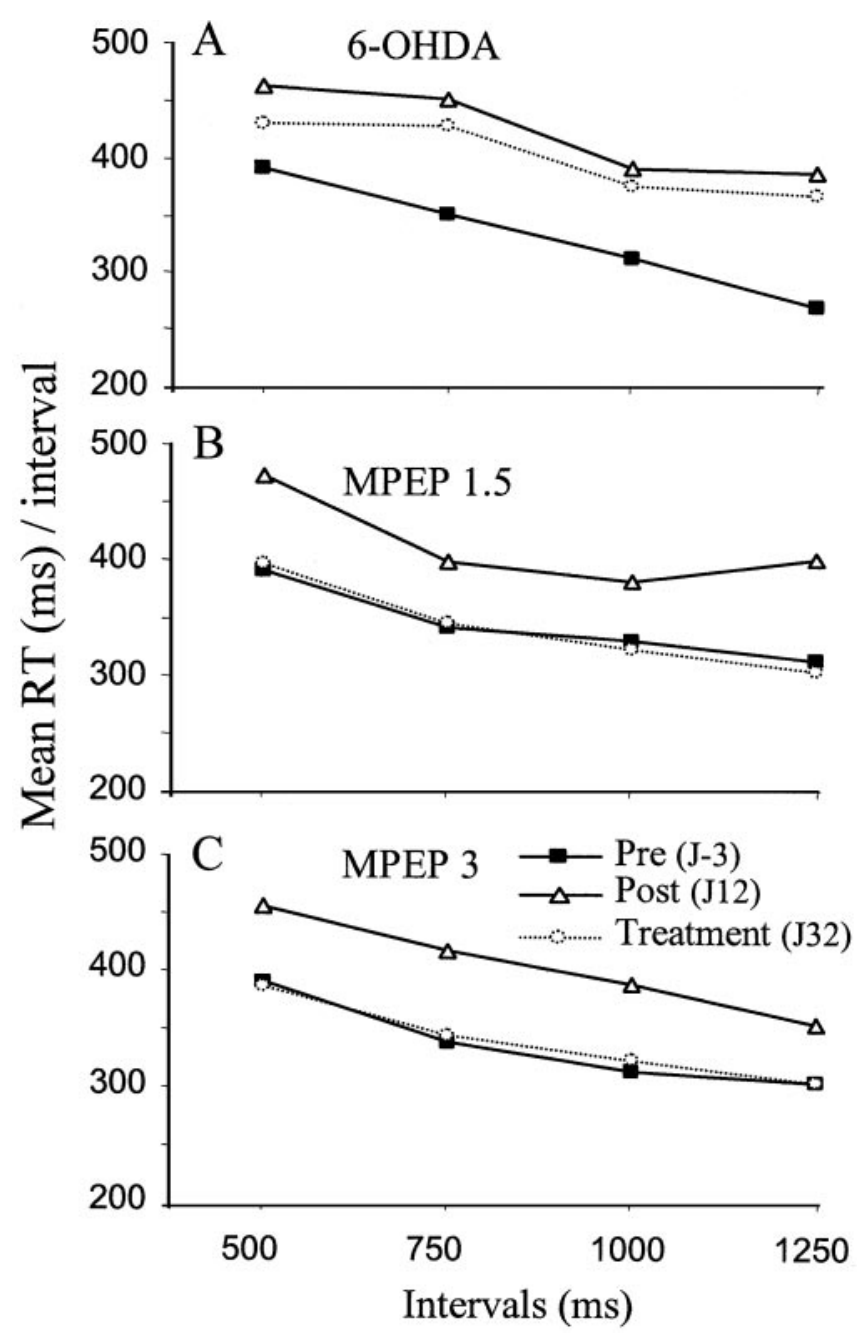

Figure 4. Effects of 6-OHDA lesion and MPEP (1.5 and $3 \mathrm{mg} / \mathrm{kg}$ ) chronic treatment on reaction time. Mean RTs are plotted as a function of the various intervals preceding the stimulus onset for the three groups of animals [6-OHDA $(n=10)$, MPEP $1.5 \mathrm{mg} / \mathrm{kg}(n=7)$, and MPEP 3 $\mathrm{mg} / \mathrm{kg}(n=10)]$. Mean RTs were measured during three representative sessions: a preoperative day $(J-3)$ and two postoperative days (J12 and $J 32)$ corresponding to the lesion effect without treatment in comparison with the end of chronic treatment, respectively.

of PD and the dyskinetic movements induced by long-term L-DOPA treatment (Benabid et al., 1994; Limousin et al., 1995a,b). In parallel, pharmacotherapies have been dedicated to modulating glutamate transmission with compounds acting at the mGluR subtypes in addition to the classical DA replacement therapy.

Because of its strategically interesting expression pattern within the basal ganglia, the mGluR5 subtype was considered a serious target for the pharmacological treatment of PD. In situ hybridization and immunohistochemistry studies reported a high level of mGluR5 expression in the striatum and a moderate labeling in the STN and its output structures, the external segment of the globus pallidus, GPi, and $\mathrm{SNr}$ in the rat (Testa et al., 1994; Shigemoto and Mizuno, 2000). Furthermore, in these basal ganglia structures, the group I mGluRs are located primarily at postsynaptic sites (Tallaksen-Greene et al., 1998; Hanson and Smith, 1999; Awad et al., 2000; Hubert et al., 2001). MPEP could

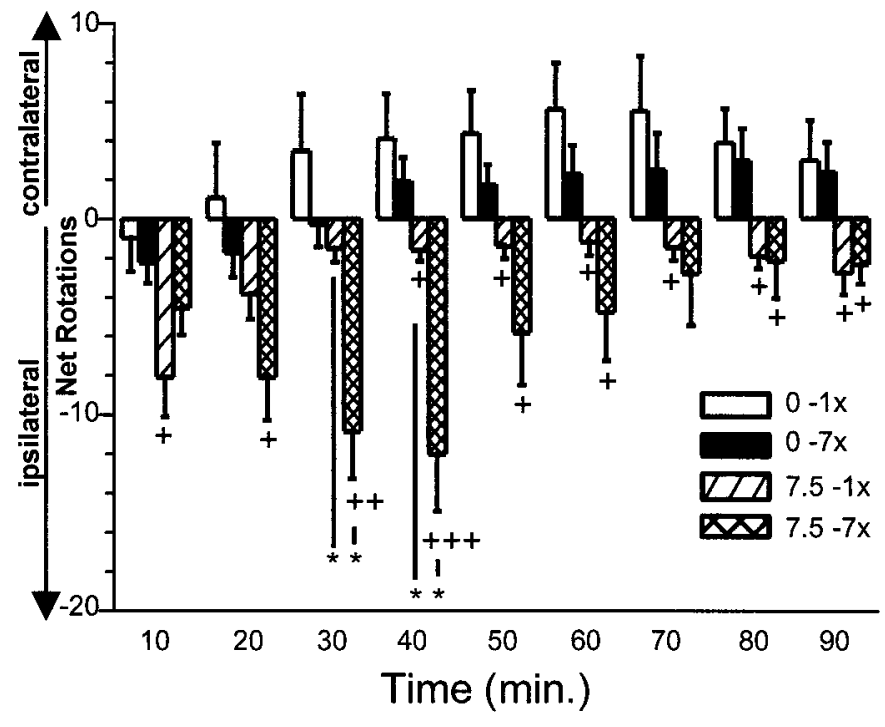

Figure 5. Acute or chronic treatment of MPEP on turning behavior. Error bars represent the mean $( \pm \mathrm{SEM})$ number of net rotations ( $=$ the number of contralateral minus ipsilateral rotations; positive value indicates contralateral turning preference and a negative value indicates ipsilateral turning preference) per $10 \mathrm{~min}$ interval during $90 \mathrm{~min}$ of registration after a single $(1 \times)$ or chronic $(7 \times)$ application of vehicle (0.5\% methylcellulose) or MPEP $(7.5 \mathrm{mg} / \mathrm{kg}$, p.o. $) .{ }^{+} p<0.05 ;{ }^{++} p<$ $0.01 ;{ }^{++} p<0.01$ versus respective $(1 x$ or $7 x$ ) vehicle treatment (unpaired $t$ test); **p $<0.01$ for the indicated comparison (paired $t$ test).

therefore produce its beneficial anti-parkinsonian effect by reducing the excessive glutamatergic drive on GABAergic output pathways of the basal ganglia and thereby counteracting the shutdown of thalamocortical projections. In addition, MPEP might also directly inactivate mGlu5 receptors in the striatum and modulate the neurotransmission of the output pathways. In agreement with this, recent behavioral studies have pointed out the role of group I or II mGluRs agonists in the nucleus accumbens in the generation and regulation of locomotion in a dopamine-dependent manner (Sacaan et al., 1992, Attarian and Amalric, 1997; Vezina and Kim, 1999; Swanson and Kalivas, 2000; Breysse et al., 2002). A possible mechanism to explain the restoration of normal motor function by MPEP is an increase in the DA level in the striatum, and this could be achieved in a partially inactivated DA system. This is further suggested in our partial model of 6-OHDA lesions in which intact DA nerve terminals may still be functionally active and possibly modulated by MPEP treatment. The present model involves a progressive neurodegeneration of DA neurons that may represent the preclinical stages of PD. These dopaminergic lesions are known to produce specific impairments in motor planning that were not compensated for several weeks after the lesion (Amalric and Koob, 1987; Amalric et al., 1995), and the major deficits, reflected by an increase in the number of delayed responses, are also observed in parkinsonian patients tested in similar RT tasks. Under these conditions, the behavioral progressive recovery of preoperative performance observed after chronic MPEP is similar to that obtained after chronic L-DOPA treatment in the same RT task and might constitute an alternative to the classic L-DOPA therapy (Maurin et al., 2001).

The beneficial effect of MPEP on parkinsonian-like deficits might also be explained by an interaction between group I mGlu and NMDA receptors that are known to be colocalized in different areas of the CNS such as the hippocampus, striatum, STN, 


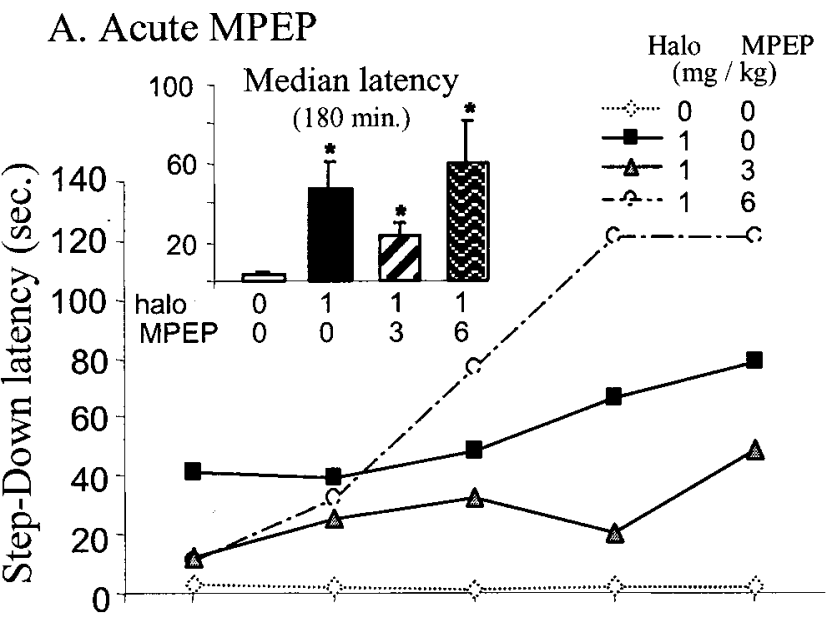

B. Chronic MPEP

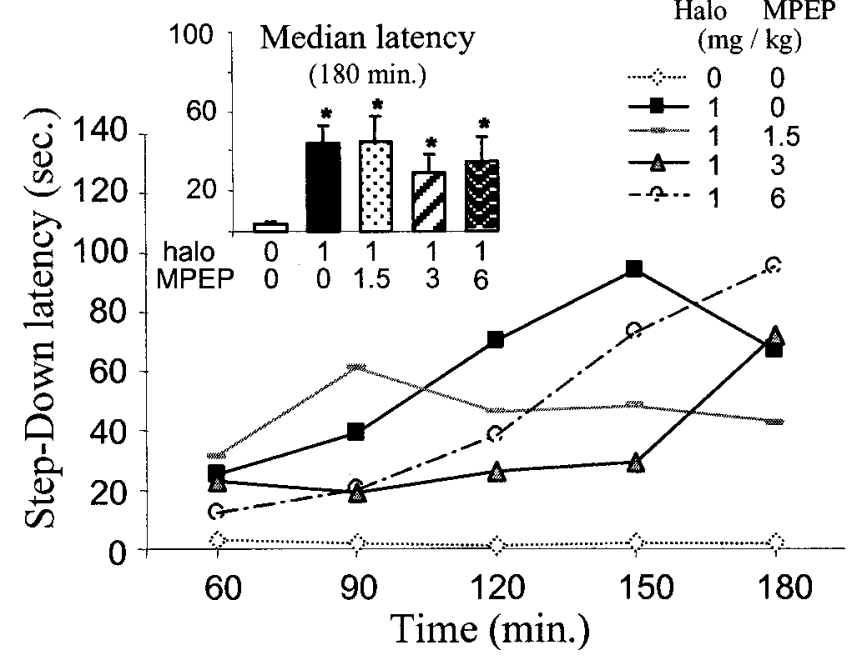

Figure 6. Acute or chronic MPEP treatment on haloperidol-induced catalepsy. The animals were tested every $20 \mathrm{~min}$ after the haloperidol injection $(1 \mathrm{mg} / \mathrm{kg}$, i.p.). $A$, Effects of acute treatment of MPEP on the median latency to step down a rod located $9 \mathrm{~cm}$ above the floor $(n=6$ by dose of MPEP; $n=8$ for control animals). Inset shows the mean median latency $( \pm \mathrm{SEM})$ during the total duration of the test $(180 \mathrm{~min}) . B$, Effects of chronic MPEP treatment at doses of $1.5,3$, and $6 \mathrm{mg} / \mathrm{kg}(n=8$ each dose) on catalepsy.

and thalamus in rat (Fitzjohn et al., 1996; Doherty et al., 1997; Pisani et al., 1997; Awad et al., 2000; Salt and Binns, 2000). For instance, Awad et al. (2000) reported that the activation of mGluR5 has direct excitatory effects and potentiates NMDA receptor currents in neurons of the STN, thereby increasing burst firing. Blockade of mGluR5 receptors with MPEP will thus exert a negative modulatory action on NMDA responses, thus reducing STN activity, and ultimately improve the motor deficits produced by the dopaminergic lesion.

Pharmacological attempts to reduce excessive glutamate activity in the basal ganglia have been achieved with NMDA receptor blockade in animal models of PD (Greenamyre et al., 1991; Schmidt et al.,1992; Baunez et al., 1994; Ossowska, 1994; Amalric et al., 1995; Ossowska et al., 1996; Lorenc-Koci et al., 1998). These studies have yielded only limited success, basically because of considerable side effects induced by some compounds that were envisioned to have therapeutic benefit (Schmidt et al., 1992;
Schmidt, 1994; Amalric et al., 1995). Clinical data suggest that undesirable effects might also be predicted to occur in humans (Ossowska et al., 1994; Andine et al., 1999). The subtype selectivity of MPEP and the modulatory action of the mGluRs on glutamatergic transmission may be responsible for the beneficial effect displayed by MPEP in comparison with NMDA antagonists.

A 3 week chronic treatment of MPEP is necessary to reverse the deficits produced by the bilateral 6-OHDA model of PD in the RT task, whereas acute injection has no effect. Furthermore, chronic MPEP administration produced a clear ipsilateral rotational response, whereas only a weak effect was observed previously in the same unilateral 6-OHDA lesion model after an acute injection of MPEP (Spooren et al., 2000). The fact that mGluRs mediate modulatory effects of synaptic transmission by the activation of a number of intracellular metabolic pathways (Pin and Duvoisin, 1995; Schoepp et al., 1999) may explain these findings. Recent molecular studies indeed suggested an important role for Homer protein complexes in the regulation of trafficking and surface expression of group I mGluRs (Roche et al., 1999; Xiao et al., 2000). Behavioral correlates of this regulation have been suggested by Swanson et al. (2001) to explain the reduction of locomotor activation induced by a group I mGluR agonist in the nucleus accumbens after repeated cocaine administration. This chronic treatment produced long-term attenuation of group I mGluR function, and this diminished function was associated with decreased levels of mGluR5 and Homer $1 \mathrm{~b} / \mathrm{c}$ protein. In line with the idea that Homer $1 \mathrm{a} / \mathrm{b} / \mathrm{c}$ proteins are involved in the targeting of mGluR5 to the dendritic sites and axons and that this effect is regulated by neuronal activity (Ango et al., 2000), we suggest that MPEP chronic treatment acts in reducing neuronal hyperactivity in the different basal ganglia structures by dynamically regulating mGluR5 distribution in the neurons. This may lead to a stronger reduction of the transduction pathway than acute blockade with MPEP (Ango et al., 2001). This effect might not be observed in a pharmacological model of PD using DA receptor antagonists. Indeed, it was reported recently that acute MPEP treatment was able to antagonize the catalepsy and muscle rigidity induced by haloperidol (Ossowska et al., 2001). The present findings using a similar cataleptic test show that the reversal of catalepsy is clearly dependent on the dose tested and that chronic treatment with MPEP does not potentiate the antiparkinsonian-like effect of acute administration. These discrepant results might be explained by the different doses of haloperidol used ( $0.5 \mathrm{vs} 1 \mathrm{mg} / \mathrm{kg}$ in the present study). As suggested above, a large blockade of DA receptors would prevent the functional interaction between group I mGluRs and DA activity existing in normal conditions (Meeker et al., 1998; David and Abraini, 2001).

In conclusion, the data presented here suggest that mGluR5 may be a particularly interesting target for modifying the glutamatergic hyperactivity within basal ganglia circuitry observed in PD. Chronic treatment with MPEP when used at an appropriate dosage may be considered a nonsurgical approach to the treatment of PD without adding side effects. Combined long-term treatment with subthreshold doses of MPEP and NMDA receptor antagonists and L-DOPA could therefore provide new therapeutic benefits that bypass the problems inherent with DA therapy.

\section{REFERENCES}

Amalric M, Koob GF (1987) Depletion of dopamine in the caudate nucleus but not in nucleus accumbens impairs reaction-time performance in rats. J Neurosci 7:2129-2134. 
Amalric M, Baunez C, Nieoullon A (1995) Does the blockade of excitatory amino acid transmission in the basal ganglia simply reverse reaction time deficits induced by dopamine inactivation? Behav Pharmacol 6:508-519.

Andine P, Widermark N, Axelsson R, Nyberg G, Olofsson U, Martensson E, Sandberg M (1999) Characterization of M K-801-induced behavior as a putative rat model of psychosis. J Pharmacol Exp Ther 290:1393-1408.

Ango F, Pin JP, Tu JC, Xiao B, Worley PF, Bockaert J, Fagni L (2000) Dendritic and axonal targeting of type 5 metabotropic glutamate receptor is regulated by Homer1 proteins and neuronal excitation. J Neurosci 20:8710-8716.

Ango F, Prézeau L, Muller T, Tu JC, Xiao B, Worley PF, Pin JP, Bockaert J, Fagni L (2001) Agonist-independent activation of metabotropic glutamate receptors by the intracellular protein Homer. Nature 411:962-965.

Attarian S, Amalric M (1997) Microinfusion of the metabotropic glutamate receptor agonist $1 S, 3 R$-1-aminocyclopentane-1,3-dicarboxylic acid into the nucleus accumbens induces dopamine-dependent locomotor activation in the rat. Eur J Neurosci 9:809-816.

Awad H, Hubert GW, Smith Y, Levey AI, Conn PJ (2000) Activation of metabotropic glutamate receptor 5 has direct excitatory effects and potentiates NMDA receptor currents in neurons of the subthalamic nucleus. J Neurosci 20:7871-7879.

Baron MS, Wichmann T, Ma D, Delong MR (2002) Effects of transient focal inactivation of the basal ganglia in parkinsonian primates. J Neurosci 22:592-599.

Baunez C, Nieoullon A, Amalric M (1994) N-methyl-D-aspartate receptor blockade impairs behavioural performance of rats in a reaction time task: new evidence for glutamatergic-dopaminergic interactions in the striatum. Neuroscience 61:521-531.

Baunez C, Nieoullon A, Amalric M (1995) In a rat model of parkinsonism, lesions of the subthalamic nucleus reverse increases of reaction time but induce a dramatic premature responding deficit. J Neurosci 15:6531-6541.

Benabid AL, Pollak P, Gross C, Hoffmann D, Benazzouz A, Gao DM, Laurent A, Gentil M, Perret J (1994) Acute and long-term effects of subthalamic nucleus stimulation in Parkinson's disease. Stereotact Funct Neurosurg 62:76-84.

Benazzouz A, Gao DM, Ni ZG, Piallat B, Bouali-Benaouzzz R, Benabid AL (2000) Effects of high-frequency stimulation of the subthalamic nucleus on the neuronal activities of the substantia nigra pars reticulata and ventrolateral nucleus of the thalamus in the rat. Neuroscience 99:289-295.

Bergman H, Wichmann T, DeLong MR (1990) Reversal of experimental parkinsonism by lesions of the subthalamic nucleus. Science 249:1436-1438.

Beurrier C, Bioulac B, Audin J, Hammond C (2001) High-frequency stimulation produces a transient blockade of voltage-gated currents in subthalamic neurons. J Neurophysiol 85:1351-1356.

Breysse N, Risterucci C, Amalric M (2002) $\mathrm{D}_{1}$ and $\mathrm{D}_{2}$ dopamine receptors contribute to the locomotor response induced by group II mGluRs activation in the rat nucleus accumbens. Psychopharmacol Biochem Behav, in press.

Carlsson M, Carlsson A (1989) The NMDA antagonist MK-801 causes marked locomotor stimulation in monoamine-depleted mice. J Neural Transm 75:221-226.

Conn PJ, Pin JP (1997) Pharmacology and functions of metabotropic glutamate receptors. Annu Rev Pharmacol Toxicol 37:205-237.

Danysz W, Parsons CG, Kornhuber J, Schmidt WJ, Quack G (1997) Aminoadamantanes as NMDA receptor antagonists and antiparkinsonian agents-preclinical studies. Neurosci Biobehav Rev 21:455-468.

David HN, Abraini JH (2001) The group I metabotropic glutamate receptor antagonist S-4-CPG modulates the locomotor response produced by the activation of D1-like, but not D2-like, dopamine receptors in the rat nucleus accumbens. Eur J Neurosci 13:2157-2164.

Doherty AJ, Palmer MJ, Henley JM, Collingridge GL, Jane DE (1997) $(R S)$-2-chloro-5-hydroxyphenylglycine (CHPG) activates mGlu5, but no mGlu1, receptors expressed in CHO cells and potentiates NMDA responses in the hippocampus. Neuropharmacology 36:265-267.

Fitzjohn SM, Irving AJ, Palmer MJ, Harvey J, Lodge D, Collingridge GL (1996) Activation of group I mGluRs potentiates NMDA responses in rat hippocampal slices. Neurosci Lett 203:211-213.

Gasparini F, Lingenhohl K, Stoehr N, Flor PJ, Heinrich M, Vranesic I, Biollaz M, Allgeier H, Heckendorn R, Urwyler S, Varney MA, Johnson EC, Hess SD, Rao SP, Sacaan AI, Santori EM, Velicelebi G, Kuhn R (1999) 2-Methyl-6-(phenylethynyl)-pyridine (MPEP), a potent, selective and systemically active mGlu5 receptor antagonist. Neuropharmacology 38:1493-1503.

Greenamyre JT, O'Brien CF (1991) N-methyl-D-aspartate antagonists in the treatment of Parkinson's disease. Arch Neurol 48:977-981.

Hanson JE, Smith Y (1999) Group I metabotropic glutamate receptors at GABAergic synapses in monkeys. J Neurosci 19:6488-6496.

Hubert GW, Paquet M, Smith Y (2001) Differential subcellular localiza- tion of mGluR1a and mGluR5 in the rat, monkey substantia nigra. J Neurosci 21:1838-1847.

Javitch JA, Strittmatter SM, Snyder SH (1985) Differential visualization of dopamine and norepinephrine uptake sites in rat brain using ${ }^{3} \mathrm{H}$ mazindol autoradiography. J Neurosci 5:1513-1521.

Limousin P, Pollak P, Benazzouz A, Hoffmann D, Broussolle E, Perret JE, Benabid AL (1995a) Bilateral subthalamic nucleus stimulation for severe Parkinson's disease. Mov Disord 10:672-674.

Limousin P, Pollak P, Benazzouz A, Hoffmann D, Le Bas JF, Broussolle E, Perret JE, Benabid AL (1995b) Effect of parkinsonian signs and symptoms of bilateral subthalamic nucleus stimulation. Lancet 345:91-95.

Lorenc-Koci E, Konieczny J, Wolfarth S (1998) Contribution of the glycine site of NMDA receptors in rostral and intermediate-caudal parts of the striatum to the regulation of muscle tone in rats. Brain Res 793:315-320.

Maurin B, Baunez C, Bonhomme C, Chezaubernard C, Nieoullon A, Amalric M (2001) Cognitive deficits in 6-OHDA lesioned rats are improved by a chronic treatment with the dopamine agonist piribedif. Behav Pharmacol 12[Suppl 1]:S63.

Meeker D, Kim JH, Vezina P (1998) Depletion of dopamine in the nucleus accumbens prevents the generation of locomotion by metabotropic glutamate receptor activation. Brain Res 812:260-264.

Ossowska K (1994) The role of excitatory amino acids in experimental models of Parkinson's disease. J Neural Transm Parkinson's Dis Dementia Sect 8:39-71.

Ossowska K, Lorenc-Koci E, Wolfarth S (1994) Antiparkinsonian action of MK-801 on the reserpine-induced rigidity: a mechanomyographic analysis. J Neural Transm Parkinson's Dis Dementia Sect 7:143-152.

Ossowska K, Lorenc-Koci E, Schulze G, Wolfarth S (1996) The influence of dizocilpine (MK-801) on the reserpine-enhanced electromyographic stretch reflex in rats. Neurosci Lett 203:73-76.

Ossowska K, Konieczny J, Wolfarth S, Wieronska J, Pilc A (2001) Blockade of the metabotropic glutamate receptor subtype 5 (mGluR5) produces antiparkinsonian-like effects in rats. Neuropharmacology 41:413-420.

Paxinos G, Watson C (1986) The rat brain in stereotaxic coordinates, Ed 2. Sydney: Academic.

Pellegrino LJ, Pellegrino AS, Cushman AJ (1997) A stereotaxic atlas of the rat brain. New York: Plenum.

Pin JP, Duvoisin R (1995) The metabotropic glutamate receptors: structure and functions. Neuropharmacology 34:1-26.

Pisani A, Calabresi P, Centonze D, Bernardi G (1997) Enhancement of NMDA responses by group I metabotropic glutamate receptor activation in striatal neurones. Br J Pharmacol 120:1007-1014.

Roche KW, Tu JC, Petralia RS, Xiao B, Wenthold RJ, Worley PF (1999) Homer $1 \mathrm{~b}$ regulates the trafficking of group I metabotropic glutamate receptors. J Biol Chem 274:25953-25957.

Rouse ST, Marino MJ, Bradley SR, Awad H, Wittmann M, Conn PJ (2000) Distribution and roles of metabotropic glutamate receptors in the basal ganglia motor circuit: implications for treatment of Parkinson's disease and related disorders. Pharmacol Ther 88:427-435.

Sacaan AI, Bymaster FP, Schoepp DD (1992) Metabotropic glutamate receptor activation produces extrapyramidal motor system activation that is mediated by striatal dopamine. J Neurochem 59:245-251.

Salt TE, Binns KE (2000) Contributions of mGlu1 and mGlu5 receptors to interactions with $N$-methyl-D-aspartate receptor-mediated responses and nociceptive sensory responses of rat thalamic neurons. Neuroscience 100:375-380.

Schmidt WJ (1994) Behavioural effects of NMDA-receptor antagonists. J Neural Transm [Suppl] 43:63-69.

Schmidt WJ, Bubser M, Hauber W (1990) Excitatory amino acids and Parkinson's disease. Trends Neurosci 13:46-47.

Schmidt WJ, Bubser M, Hauber W (1992) Behavioural pharmacology of glutamate in the basal ganglia. J Neural Transm [Suppl] 38:65-89.

Schoepp DD, Jane DE, Monn JA (1999) Pharmacological agents acting at subtypes of metabotropic glutamate receptors. Neuropharmacology 38:1431-1476.

Shigemoto R, Mizuno N (2000) Metabotropic glutamate receptors-immunocytochemical and in situ hybridization analyses. In: Handbook of chemical neuroanatomy, Vol 18 (Ottersen OP, Storm-Mathisen J, eds), pp 63-98. New York: Elsevier Science.

Spooren WP, Waldmeier P, Gentsch C (1999) The effect of a subchronic post-lesion treatment with (-)-deprenyl on the sensitivity of 6-OHDAlesioned rats to apomorphine and D-amphetamine. J Neural Transm 106:825-833.

Spooren WP, Gasparini F, Bergmann R, Kuhn R (2000) Effects of the prototypical $\mathrm{mGlu}(5)$ receptor antagonist 2-methyl-6-(phenylethynyl)pyridine on rotarod, locomotor activity and rotational responses in unilateral 6-OHDA-lesioned rats. Eur J Pharmacol 406:403-410.

Spooren WP, Gasparini F, Salt TE, Kuhn R (2001) Novel allosteric antagonists shed light on mglu(5) receptors and CNS disorders. Trends Pharmacol Sci 22:331-337.

Starr MS, Starr BS, Kaur S (1997) Stimulation of basal and L-DOPA- 
induced motor activity by glutamate antagonists in animal models of Parkinson's disease. Neurosci Biobehav Rev 21:437-446.

Swanson CJ, Kalivas PW (2000) Regulation of locomotor activity by metabotropic glutamate receptors in the nucleus accumbens and ventral tegmental area. J Pharmacol Exp Ther 292:406-414.

Swanson CJ, Baker DA, Carson D, Worley PF, Kalivas PW (2001) Repeated cocaine administration attenuates group I metabotropic glutamate receptor-mediated glutamate release and behavioural activation: a potential role for Homer. J Neurosci 21:9043-9052.

Tallaksen-Greene SJ, Kaatz KW, Romano C, Albin RL (1998) Localization of mGluR1a-like immunoreactivity and mGluR5-like immunoreactivity in identified populations of striatal neurons. Brain Res 780:210-217.

Testa CM, Standaert DG, Young AB, Penney JB Jr (1994) Metabotropic glutamate receptor mRNA expression in the basal ganglia of the rat. J Neurosci 14:3005-3018.
Vezina P, Kim JH (1999) Metabotropic glutamate receptors and the generation of locomotor activity: interactions with midbrain dopamine. Neurosci Biobehav Rev 23:577-589.

Vila M, Levy R, Herrero MT, Ruberg M, Faucheux B, Obeso JA, Agid Y, Hirsch EC (1997) Consequences of nigrostriatal denervation on the functioning of the basal ganglia in human and nonhuman primates: an in situ hybridization study of cytochrome oxidase subunit I mRNA. J Neurosci 17:765-773.

Wichmann T, DeLong MR (1997) Physiology of the basal ganglia and pathophysiology of movement disorders of basal ganglia origin. In: Movement disorders: neurological principles and practice (Watts RL, ed), pp 87-97. New York: McGraw-Hill.

Xiao B, Tu JC, Worley PF (2000) Homer: a link between neural activity and glutamate receptor function. Curr Opin Neurobiol 9:299-304 